Jurnal Pemberdayaan: Publikasi Hasil Pengabdian kepada Masyarakat

Vol. 2, No. 3, Desember 2018, Hal. 399-406

ISSN: 2088 4559; e-ISSN: XXXX-XXXX

DOI:

\title{
WORKSHOP TEACHING MATHEMATICS IN ENGLISH BAGI GURU- GURU SMP MUHAMMADIYAH SE-KOTA YOGYAKARTA
}

\author{
Abdul Taram ${ }^{1}$, Afit Istiandaru ${ }^{2}$ \\ Universitas Ahmad Dahlan, Yogyakarta, ${ }^{1,2}$ \\ Email: afit.istiandaru@pmat.uad.ac.id ${ }^{2}$
}

\begin{abstract}
ABSTRAK
Pembelajaran matematika berbahasa Inggris merupakan salah satu skill tambahan menjadi guru yang unggul terutama di era globalisasi. Banyak sekolah juga memiliki program kelas unggulan dengan salah satu kriteria unggulannya adalah kelas berbahasa Inggris, salah satunya adalah SMP Muhammadiyah 1 Yogyakarta. Untuk masuk kelas ini, siswa baru harus melewati seleksi Bahasa Inggris. Hal yang sama ditunjukkan oleh SMP Muhammadiyah 2 dan SMP Muhammadiyah 3 Yogyakarta. Sekolah-sekolah tersebut juga memberikan perhatian pada kemampuan berbahasa asing para siswanya. Tujuan kegiatan pengabdian ini adalah untuk melatih dan memotivasi guru agar mampu menyusun RPP dan menyiapkan materi matematika berbahasa Inggris. Kegiatan pengabdian dilaksanakan dalam dua tahapan, yaitu workshop dan pendampingan. Hasil kegiatan pengabdian menunjukkan bahwa para guru telah mampu menyusun RPP berbahasa Inggris hasil workshop dan kegiatan mandiri dengan baik. Adapun umpan balik yang diperoleh menunjukkan bahwa guru optimis tujuan workshop dapat tercapai. Daya dukung workshop berupa fasilitas ruang maupun fasilitas pendukung cukup memadai sehingga workshop bisa berjalan dengan lancar, baik, tepat waktu, dan menyenangkan. Persepsi peserta terhadap kebermanfaatan program juga baik.
\end{abstract}

Kata Kunci: Teaching mathematics in English, RPP

\begin{abstract}
Learning mathematics in English is one of the additional skills to become a great teacher, especially in the globalization era. Many schools also have excellent class programs with one of the superior criteria being English-speaking classes, one of them is Muhammadiyah 1 Middle School in Yogyakarta. To enter this class, new students must pass the English selection. It's same with Muhammadiyah 2 Middle School and Muhammadiyah 3 Middle School in Yogyakarta. The schools also pay attention to the foreign language skills of their students. The purpose of this activity is to train and motivate teachers to be able to compile lesson plans and prepare mathematics material in English. Service activities are carried out in two stages, namely workshops and facilitator. The results of the community service activities show that the teachers have been able to prepare a lesson plan in English-language as the result of workshops and independent activities properly. The feedback obtained shows that the teacher is optimistic that the workshop objectives can be achieved. The support capacity of the workshop such as the room facilities and also supporting facilities is sufficient enough so that the workshop can work smoothly, well, on time, and joyful. Participants' perceptions of the usefulness of the program are also good.
\end{abstract}

Keywords: Teaching mathematics in English, Lesson Plan 


\section{PENDAHULUAN}

SMP Muhammadiyah 1, SMP Muhammadiyah 2, dan SMP Muhammadiyah 3 Yogyakarta merupakan tiga dari sepuluh sekolah menengah pertama di bawah naungan Majelis Dikdasmen Pimpinan Daerah Muhammadiyah Kota Yogyakarta. SMP Muhammadiyah 1 Yogyakarta beralamat di Jl. Purwodiningratan, RW.X, Ngampilan, Kota Yogyakarta; SMP Muhammadiyah 2 Yogyakarta beralamat di Jl. Kapas II No.7a, Semaki, Umbulharjo, Kota Yogyakarta; sedangkan SMP Muhammadiyah 3 Yogyakarta beralamat di Jl. Kapten Piere Tendean No.19, Wirobrajan, Kota Yogyakarta. Ketiganya termasuk sekolah yang memiliki berbagai macam program unggulan untuk siswa.

Salah satu keunggulan yang didefinisikan oleh sekolah adalah adanya program yang ditawarkan, di antaranya yang diunggulkan oleh SMP Muhammadiyah 1 Yogyakarta meliputi pembukaan Kelas Unggulan, Kelas Bahasa, Kelas IT, dan Kelas Reguler. Kelas Bahasa diperuntukkan bagi siswa yang memiliki minat dan kemampuan khusus untuk belajar bahasa asing, di antaranya: Bahasa Inggris, Bahasa Arab, dan Bahasa Jepang. Untuk masuk kelas ini, siswa baru harus melewati seleksi Bahasa Inggris. Hal yang sama ditunjukkan oleh SMP Muhammadiyah 2 dan SMP Muhammadiyah 3 Yogyakarta. Sekolah-sekolah tersebut juga memberikan perhatian pada kemampuan berbahasa asing para siswanya.

Pengusul menemukan bahwa para guru matematika belum mampu membelajarkan matematika dengan menggunakan bahasa Inggris sebagai bahasa pengantar. Hal ini disebabkan (1) belum ada rujukan istilah matematika berbahasa Inggris yang memadai, (2) belum ada RPP matematika berbahasa Inggris yang layak, dan (3) belum pernah ada workshop pembelajaran matematika menggunakan bahasa Inggris sebagai bahasa pengantar. Hal ini kontradiksi dengan kebutuhan sekolah untuk memfasilitasi para siswa agar mampu berbahasa Inggris dengan baik. Sekolah perlu mengambil langkah strategis menyikapi kebutuhan tersebut dengan penyiapan SDM (guru) yang berkualitas.

Banyak faktor yang menentukan kualitas pendidikan, namun guru tetap dipandang sebagai faktor penentu utama, karena guru yang memegang kendali pembelajaran, menentukan arah pencapaian tujuan pembelajaran, dan mengelola pembelajaran siswa (Amir, 2013; Kunandar, 2007; Jalal, 2007). Konsekuensi hal tersebut adalah bahwa guru dituntut untuk mampu membelajarkan siswa dengan baik.

Era globalisasi memposisikan bahasa Inggris sebagai lingua franca dalam kancah pergaulan internasional. Ada sekitar 479 juta orang penutur asli bahasa Inggris dan lebih dari 700 juta orang yang bisa berbahasa Inggris sebagai bahasa kedua maupun bahasa asing (Artini, 2013). Kondisi tersebut membuat hampir setiap lini pekerjaan dan beasiswa Workshop Teaching Mathematics In English Bagi Guru-Guru SMP Muhammadiyah (Abdul Taram) | 400 
mensyaratkan kemampuan berbahasa Inggris yang bagus, misalnya rekrutmen perusahaan, pegawai negeri sipil, hingga beasiswa studi lanjut. Menyikapi hal tersebut, kemampuan berbahasa Inggris hendaknya disiapkan sejak dini mulai dari pendidikan dasar. Walaupun keberadaan sekolah rintisan bertaraf internasional sudah dihapus oleh Mahkamah Konstitusi pada tahun 2013, kebutuhan kemampuan bahasa Inggris tetap tinggi dan masih menjadi keunggulan yang layak diupayakan oleh sekolah.

Pengusul menawarkan untuk perlu diadakan workshop teaching mathematics using english as medium of instruction. Workshop akan dilaksanakan memuat tiga hal, yaitu: (1) diseminasi kamus matematika berbahasa Inggris, (2) penyusunan RPP berbahasa Inggris, dan (3) praktik mengajar matematika berbahasa Inggris.

Dengan mengikuti workshop tersebut guru akan mempunyai bekal mengajar matematika berbahasa Inggris yang cukup. Di samping itu, workshop dapat memfasilitasi disusunnya RPP matematika berbahasa Inggris yang ideal. Workshop juga dapat memotivasi guru untuk meningkatkan kemampuan berkomunikasi menggunakan bahasa Inggris.

\section{METODE}

Sasaran kegiatan ini adalah guru-guru SMP/MTs Muhammadiyah se- Kota Yogyakarta. Berdasarkan data yang pernah dihimpun, terdapat 10 SMP Muhammadiyah dan 2 MTS di Kota Yogyakarta. Kegiatan pengabdian ini diikuti oleh 14 guru yang berasal dari sekolahsekolah tersebut.

Materi workshop meliputi: (1) Istilah-istilah matematika dalam bahasa Inggris; (2) RPP berdasarkan kurikulum 2013 berbahasa Inggris; (3) Materi-materi pokok matematika berbahasa Inggris; dan (4) Dasar-dasar praktik mengajar matematika berbahasa Inggris. Kegiatan pengabdian dilaksanakan dalam dua tahapan, yaitu workshop dan pendampingan. Metode pelaksanaan workshop diuraikan pada Tabel 1.

Tabel 1. Metode Pelaksanaan Workshop

\begin{tabular}{lll}
\hline No & \multicolumn{1}{c}{ Jenis Kegiatan } & \multicolumn{1}{c}{ Durasi } \\
\hline 1 & Kegiatan Terjadwal & \\
& a. Workshop & 8 jam (4 sesi x 2 jam, diselenggarakan dalam 2 hari) \\
& b. Pendampingan & 8 jam (4 sekolah x 2 jam, diselenggarakan dalam 2 hari) \\
2 & Kegiatan Tidak Terjadwal & \\
& a. Persiapan dan laporan & 4 jam \\
& b. Kegiatan mandiri & 5 jam \\
& Total & 25 jam \\
\hline
\end{tabular}




\section{HASIL, PEMBAHASAN, DAN DAMPAK}

Kegiatan PPM Reguler ini diawali dengan koordinasi bersama Majelis Dikdasmen PDM Kota Yogyakarta pada bulan November 2017, dan dilanjutkan dengan menyepakati kegiatan pertama PPM dilaksanakan pada tanggal 10 Februari 2018 di SMP Muhammadiyah 2 Yogyakarta.

Secara umum, kegiatan PPM dibagi menjadi 2 tahapan, yaitu: workshop dan pendampingan. Kegiatan workshop dilaksanakan selama 2 hari, yaitu tanggal 10 Februari 2018 dan tanggal 17 Februari 2018. Workshop hari pertama dibuka oleh Ketua Majelis Dikdasmen PDM Kota Yogyakarta, Dr. H. Ariswan, M.Si. DEA., dilanjutkan dengan sesi workshop selama 4 jam. Fokus workshop hari pertama adalah pembiasaan peserta terhadap istilah-istilah matematika berbahasa Inggris.

Pengusul mengukur kemampuan peserta berkaitan dengan penguasaan istilah-istilah matematika berbahasa Inggris dengan memberikan soal sebanyak 25 istilah berbahasa Indonesia yang harus dicari padanannya dalam bahasa Inggris, dan 25 istilah berbahasa Inggris yang harus dicari padanannya dalam bahasa Indonesia. Berdasarkan pengukuran tersebut, rata-rata peserta hanya menjawab 12 soal dengan benar. Sebagian besar peserta mengaku bahwa istilah-istilah matematika ternyata berbeda dengan istilah umum walaupun penyebutan dalam bahasa Indonesia sama. Misalnya saja, kata "bola" tidak serta merta diterjemahkan menjadi "ball" sebab objek yang dimaksud adalah objek abstrak, bukan bola yang dipakai untuk berolahraga, sehingga istilah yang lebih tepat adalah "sphere".

Lebih jauh lagi, pengusul juga mengukur persepsi peserta terhadap dua hal, yaitu: pentingnya workshop dilaksanakan dan kemampuan berbahasa Inggris yang dimiliki. Peserta diminta untuk mengukur dua hal tersebut dalam skala 1 s.d. 5 berturut-turut untuk kualitas terendah hingga tertinggi. Hasil yang diperoleh disajikan pada Tabel 2.

Tabel 2. Persepsi Awal Peserta Workshop

\begin{tabular}{llccc}
\hline No & \multicolumn{1}{c}{ Aspek } & $\begin{array}{c}\text { Respon } \\
\text { terbanyak }\end{array}$ & $\begin{array}{c}\text { Persentase } \\
\text { respon 4 \& 5 }\end{array}$ \\
\hline 1 & $\begin{array}{l}\text { Pentingnya workshop terhadap } \\
\text { kompetensi guru }\end{array}$ & pengembangan & 5 & $67 \%$ \\
2 & Kemampuan berbahasa Inggris & 2 & $0 \%$ \\
\hline
\end{tabular}

Sumber: Olah data feedback pengabdian 2017

Dari Tabel 2, diperoleh informasi bahwa kebanyakan peserta memiliki persepsi yang positif terhadap pentingnya kegiatan workshop bagi pengembangan kompetensi guru. Namun, peserta masih merasa kemampuan berbahasa Inggrisnya kurang. Selanjutnya, peserta dikenalkan dengan contoh RPP berbahasa Inggris. Pada prinsipnya, format dan rincian 
kompetensi sama dengan silabus dan RPP berbahasa Indonesia, hanya saja, penekanan pada perencanaan materi yang harus mengikuti kaidah Bahasa Inggris Matematika dan sumber belajar yang harus mengambil sumber relevan. Pada pertemuan kedua, kegiatan difokuskan pada praktik menyusun RPP berbahasa Inggris sesuai contoh. Kegiatan dilakukan berkelompok. Di akhir kegiatan, peserta berhasil mengumpulkan prototipe RPP berbahasa Inggris dengan kualitas cukup. Setelah workshop dilaksanakan dalam dua pertemuan, peserta dapat merasakan adanya manfaat workshop. Tabel 3 menunjukkan umpan balik peserta terhadap pelaksanaan workshop.

Tabel 3. Umpan Balik Peserta Workshop

\begin{tabular}{|c|c|c|c|}
\hline No & Aspek & $\begin{array}{c}\text { Respon } \\
\text { terbanyak }\end{array}$ & $\begin{array}{l}\text { Persentase } \\
\text { respon } 4 \& 5\end{array}$ \\
\hline 1 & $\begin{array}{l}\text { Kesesuaian tema workshop dengan kebutuhan } \\
\text { peningkatan profesionalisme guru }\end{array}$ & 3 & $34 \%$ \\
\hline 2 & Ketercapaian tujuan workshop & 5 & $70 \%$ \\
\hline 3 & Kesesuaian pelaksanaan workshop dengan jadwal & 5 & $76,67 \%$ \\
\hline 4 & Suasana pelatihan yang menyenangkan & 5 & $76,67 \%$ \\
\hline 5 & Kebaruan dan kemutakhiran materi & 5 & $90 \%$ \\
\hline 6 & Penguasaan materi narasumber & 5 & $90 \%$ \\
\hline 7 & Kemampuan penyampaian materi narasumber & 5 & $90 \%$ \\
\hline 8 & $\begin{array}{l}\text { Ketersediaan fasilitas pelatihan berupa kit } \\
\text { pelatihan }\end{array}$ & 5 & $90 \%$ \\
\hline 9 & $\begin{array}{l}\text { Ketersediaan fasilitas pelatihan berupa konsumsi } \\
\text { pelatihan }\end{array}$ & 5 & $96,67 \%$ \\
\hline 10 & Ketersediaan sarana pendukung selama pelatihan & 3 & $90 \%$ \\
\hline 11 & $\begin{array}{l}\text { Kesediaan peserta untuk menindaklanuti pelatihan } \\
\text { dengan kegiatan mandiri (menyusun RPP } \\
\text { berbahasa Inggris) }\end{array}$ & 3 & $34 \%$ \\
\hline 12 & Kebermanfaatan program & 4 & $70 \%$ \\
\hline
\end{tabular}

Sumber: Olah data feedback pengabdian 2018

Pada Tabel 3, terlihat bahwa peserta merespon dengan baik workshop yang diselenggarakan. Peserta optimis tujuan workshop dapat tercapai. Menurut peserta, workshop berjalan dengan baik, tepat waktu, dan menyenangkan. Daya dukung workshop berupa fasilitas ruang maupun fasilitas pendukung cukup memadai sehingga workshop bisa berjalan dengan lancar.

Aspek yang direspon kurang dari aspek-aspek yang lain adalah mengenai kesesuaian tema workshop sesuai dengan kebutuhan peningkatan profesionalisme guru dan kesediaan peserta untuk menerapkan di sekolah pascaworkshop. Kedua aspek tersebut hanya direspon masing-masing 34\% dari keseluruhan peserta. Hal ini dapat dipahami mengingat tidak semua sekolah memiliki tuntutan untuk menerapkan pembelajaran matematika berbahasa Inggris. 
Namun, peserta berpendapat bahwa ilmu yang diperoleh sangat bermanfaat bagi bertambahnya wawasan guru.

Berdasarkan analisis tersebut, perlu adanya kegiatan tindak lanjut berupa pendampingan ke sekolah-sekolah sasaran untuk memastikan diterapkannya hasil workshop di sekolah. Peserta menindaklanjuti workshop dengan kegiatan mandiri selama bulan Maret-Mei 2018. Berdasarkan wawancara terstruktur pada kegiatan pendampingan tersebut, tim menemukan bahwa secara umum para guru peserta berusaha menerapkan hasil workshop semaksimal mungkin, di antaranya dengan menyusun sendiri RPP hasil worskhop disesuaikan dengan kondisi sekolah.

\section{SIMPULAN}

Kesimpulan yang dapat diambil dari kegiatan ini adalah bahwa (1) workshop dapat berjalan dengan lancar, (2) respon peserta terhadap pelaksanaan workshop sangat bagus, (3) terdapat kendala berupa keterbatasan kemampuan berbahasa Inggris dan kurangnya motivasi guru untuk menyusun RPP berbahasa Inggris, (4) kendala tersebut diupayakan untuk diatasi dengan terus memberikan pendampingan kepada para guru hingga dihasilkan dokumen RPP berbahasa Inggris yang memadai.

Saran yang dapat direkomendasikan adalah (1) pada workshop serupa, perlu diupayakan penelitian pendahuluan sejauh mana kebutuhan peserta workshop mengimplementasikan pembelajaran matematika berbahasa Inggris di sekolah, (2) workshop perlu dikemas dalam bentuk coaching clinic di mana peserta membawa dokumen RPP untuk dikaji dan diperbaiki bersama.

\section{DAFTAR PUSTAKA}

Amir, A. (2013). Pengembangan profesionalisme guru dalam pembelajaran melalui model lesson study. Logaritma, 1(2), 130-143.

Artini, L.P. (2013). Penggunaan English as Medium of Instruction (EMI) dan Konsekuensinya terhadap Proses Pembelajaran Ditinjau dari Persepsi Siswa. Jurnal Ilmu Sosial dan Humaniora, 2(1), 166-178.

Jalal, F. (2007). Sertifikasi Guru untuk Mewujudkan Pendidikan yang Bermutu. Medan: Universitas Negeri Medan.

Kunandar. (2007). Guru Profesional Implementasi Kurikulum Tingkat Satuan Pendidikan (KTSP) dan Sukses dalam Sertifikasi Guru. Jakarta: PT. Rajagrafindo Persada. 


\section{UCAPAN TERIMA KASIH}

Tim pengabdian kepada masyarakat menyampaikan terima kasih kepada Lembaga Penelitian dan Pengabdian kepada Masyarakat (LPPM) Universitas Ahmad Dahlan yang telah mendanai, membina, dan memonitor kegiatan ini sehingga dapat berjalan lancar dan mencapai tujuan dengan baik. 
2018 Jurnal Pemberdayaan: Publikasi Hasil Pengabdian kepada Masyarakat - ISSN: 2088 4559; e-ISSN: 